\title{
On the Profile of the Baltic Journal of European Studies (BJES)
}

The essential significance of the articles published in this fifth (spring 2013) issue of the Baltic Journal of European Studies lies in a new perspective given to key issues in the field of socio-economic and international policies of the European Union. BJES is an international journal dedicated to research a wide range of issues related to the developments in the European Union and between the EU and other regions, such as China, for example. In this direction a new strategic step has been made. We would like to inform our authors and readers about a recent co-operation agreement signed between the Tallinn University of Technology and Versita Publishing in Warsaw. This agreement facilitates a broader access to our authors' writings both within the European science information space and also globally. The authors will get hundreds of new readers and supporters to their academic ideas and solutions. This expansion will enable the journal to fulfil its mission more efficiently.

In the process of globalisation, where Europe needs a new understanding of financial and economic integration concerning all EU Member States, the mission of the Baltic Journal of European Studies will be to contribute to these processes by providing an open arena for academic discussions. At the same time, people in the Baltic countries and in other EU Member States must focus on the grand challenges of our time. The increase of professional knowledge and skills among the population together with firms' development and their competitiveness within the knowledgebased economy is one contingency which will enable to change the circumstances concerning the structural side of the knowledge triangle. Overall, the global context has changed radically, and the success stories of Finland, Ireland and the Asian newly industrialised economies in the 1990 s are not directly replicable. Estonia's opportunity is to increase competitiveness of the sector of knowledge-based economy through a deeper market integration of universities and the private sector.

On the other hand, this change has to be based on attracting new capital for investments into the economy and on the development of human capital. 
We share an opinion that the journal will contribute to the studies of how to enhance human capital, while our first priority is to study and assess the economic and social issues regarding the future of the countries in the Baltic Sea Macro-Region from the perspectives of different academic disciplines.

However, we hope that the recent developments concerning our journal will help raise awareness about the Baltic Journal of European Studies among the academic community, both readers and prospective authors.

As David Ramiro Troitiño remarked in the first article of the spring issue "The Current Economic Crisis of the EU: Genesis, Analysis and Solutions", according to the permanent model of integration in Europe, the organisation always takes the Member States' policies and manages them according to a common pattern, but never returns the same policies to the states. The EU always takes, never returns. Currently, the process of Europe's construction is in a delicate stage of stagnation that will be followed by another phase of integration. The EU's current problems will be solved with more integration, but, of course, not before overcoming the reluctance of national governments of the various current EU Member States, given the gravity of the crisis that Europe is facing right now.

Lessons from the EU countries' and Russia's economic and international relations with China are particularly important for small countries of the EU members at the Baltic Sea Region and two articles demonstrate this. Juhan Värk (Estonia) in his article "Russia between China and the European Union: Friends or Foes?" and Jelena Staburova and Una Aleksandra Bērziṇa (Latvia) in their article about EU-China relationships since 2008 demonstrate a growing interest of the academic population of the Baltic countries in China in the recent years. We can resume that as in China (and in Estonia and Latvia), the future development vision of China's new President Xi Jinping would be beneficial both to the people of China and the academic circles in the Baltic countries. 
Mait Talts in his comprehensive article "Some Aspects of the Baltic Countries' Pre- and Post-Accession Convergence to the European Union" provides an overview of the broader process of political, legal and societal changes characterising the Baltic countries' convergence towards the European Union. It is a very useful read, suggesting that the differences between Estonia and Lithuania mostly derive from the somewhat different culture, mentality, expectations and subjective worldview of these nations, which result in different evaluations of similar developments. The Baltic countries' economic and social developments have been surprisingly similar throughout the past ten years - in the longer run it might cause major changes in mentality in Lithuania, bringing the Lithuanians' mindset closer to the other Baltic nations. The developments of the most recent years, however, seem to suggest Latvia's deviation from the course of development of the other Baltic countries, but whether this will become a reality, will be for the future to decide.

Maria Claudia Solarte-Vasquez in her very original article "Regulatory patterns of the Internet development: Expanding the role of private stakeholders through mediatised 'self-regulation"' studies the Internet from an evolutionary point of view, based on historic, institutional and legal analysis. The author makes a novel concluding claim that the Internet and telecommunication technologies in general, considered as enabling mediums, would benefit from dynamic and mixed regulatory solutions, according to and depending on whether their object is their infrastructure or the surface layer of its applications.

Eva Branten and Alari Purju in their article "Innovative Financial Instruments in the EU Funding Schemes" have focused on the most meaningful problems in innovation policy in the European Union. The article presents the potential social benefits and costs of innovative financial instruments and ways to measure their impact and concludes with some recommendations regarding the use of innovative financial instruments in Estonia. 
Helbe Põdder in her article "Nation-state 'political ineptitude' revealed in a citizen's identity processes? A case study using Identity Structure Analysis" demonstrate the efficacy of Identity Structure Analysis for elucidating complex identity processes in socio-historical and biographical context.

David Laitin (Stanford University) gave a lecture on the topic "The Uniting of Europe: A Memoir of Ernst B. Haas" on 5 March 2013 for students and professors of the Tallinn University of Technology. This was a highly interesting talk about Ernst Haas, the lecturer's best teacher and great scholar, Europeanist. For Ernst Haas as a Neo-functionalist, the key was to how nations could build international institutions to build new institutions and by so doing, relinquishing their authority over to their own populations by their own free will.

As David Laitin said, Ernst Haas was very original in his theoretical works, having resumed in his 1958 study: So self-interest creates conflict, conflict which leads to new institutions, new institutions create demands for every new institutions - that is the "spill-over" factor. And with "spill-over" you get the change in a locus of authority and political unity. It is not love for each other but desire to defeat one another in political allocated decisions, which drives political unity. It is not human goodness, but human self-interest which is behind the Neo-functionalist theory. 